\title{
The influence of a high-protein, low-carbohydrate diet on bone development in the fetuses of rat dams with streptozotocin-induced diabetes
}

\author{
BY W. KEITH HARVEY ${ }^{1}$ AND TETSUO NAKAMOTO ${ }^{2, *}$ \\ Laboratory of Perinatal Nutrition and Metabolism, Departments of ${ }^{1}$ Orthodontics and \\ ${ }^{2}$ Physiology, Louisiana State University Medical Center, New Orleans, LA 70119, USA
}

(Received 28 April 1987 - Accepted 16 September 1987)

1. The purpose of the present study was to determine the effects of diet on the mandibles and growth centres of the long bones in the fetuses of diabetic rat dams given a normal diet compared with those given a high-protein, low-carbohydrate diet.

2. On the 9 th day of gestation, the controls, groups $I$ and 3, were injected with citrate buffer and given 200 and $600 \mathrm{~g}$ protein $/ \mathrm{kg}$ diets respectively. Groups 2 and 4 were injected with $40 \mathrm{mg}$ streptozotocin $/ \mathrm{kg}$ body-weight and pair-fed with groups 1 and 3 respectively on the 200 and $600 \mathrm{~g}$ protein $/ \mathrm{kg}$ diets.

3. On day 22 , some dams were injected with either ${ }^{45} \mathrm{Ca}$ or $\left[{ }^{14} \mathrm{C}\right]$ proline. Mandibles and long bones were removed and weighed and analysed for $\mathrm{Ca}$ content, ${ }^{45} \mathrm{Ca}$ uptake, collagen and collagen synthesis.

4. The body-weights, and mandibular and long-bone weights of the fetuses in the diabetic $200 \mathrm{~g} \mathrm{protein} / \mathrm{kg}$ group were smaller than those of the non-diabetic $200 \mathrm{~g}$ protein $/ \mathrm{kg}$ group, whereas those of the diabetic $600 \mathrm{~g}$ protein $/ \mathrm{kg}$ group showed no difference from the non-diabetic $600 \mathrm{~g}$ protein $/ \mathrm{kg}$ group.

5. The rate of collagen synthesis was higher in the fetuses of the diabetic $600 \mathrm{~g}$ protein $/ \mathrm{kg}$ group than those of the non-diabetic group. Bones of the diabetic $200 \mathrm{~g}$ protein $/ \mathrm{kg}$ group were lower in collagen content when compared with the non-diabetic group, whereas there was no difference between the diabetic and non-diabetic $600 \mathrm{~g}$ protein $/ \mathrm{kg}$ groups.

6. Ca uptake and total $\mathrm{Ca}$ contents in the mandibles and long bones showed no difference between diabetic and non-diabetic groups fed on both diets.

7. A high-protein, low-carbohydrate diet appeared to have a certain beneficial effect on bone development of the growing fetuses from diabetic dams.

Juvenile diabetes results in alterations in bone development. Significant findings include an overall reduction in bone formation as well as a decrease in osteon formation (Kelvin \& Frost, 1964). In addition, diabetics often suffer from an increased incidence of traumatic bone fractures (Lewis et al. 1976), possibly relating to their high incidence of osteoporosis. Osteoporosis results from a decrease in calcium deposition in bone (Dixit \& Stern, 1979). Insulin has been shown to stimulate amino acid uptake in bone (Hahn et al. 1971), collagen synthesis (Wettenholl et al. 1969) and intestinal Ca absorption (Schneider \& Schedl, 1972). Therefore, alterations in bone metabolism are to be expected in the absence of insulin. Decrease in vivo endochondral bone growth and development during streptozotocininduced diabetes is due to the inhibition of insulin-dependent mesenchymal cell proliferation, resulting in delayed cartilage formation and decreased vascular invasion before chondrolysis and osteogenesis (Weiss \& Reddi, 1980). Other findings suggest a generalized increase in the activity of enzymes involved in the synthesis and degradation of glycosaminoglycans, one of the constituents of the ground substance of bone (Silberberg et al. 1977).

Dietary regulation results in a reduction in hyperglycaemia and glycosuria as well as providing adequate metabolic control in the clinically-induced diabetic rat (Siegel et al. 1976). Although a diet in which carbohydrate intake is restricted has historically been advocated for the diabetic, very little information exists concerning the effects of maternal dietary intake on the developing fetus. Since fetuses are growing rapidly during gestation,

* For reprints. 
it is likely that nutritional manipulation such as high-protein, low-carbohydrate diets during this period could greatly alter the metabolism of fetal bones. Thus, such dietary regulation of the diabetic dams may have positive effects on bone development in the fetuses born from these dams.

We have selected a high-protein diet $(600 \mathrm{~g} / \mathrm{kg})$, which may influence bone metabolism in a diabetic state, in the absence of exogenous insulin supplementation, and compared it with a normal protein diet $(200 \mathrm{~g} / \mathrm{kg})$. In the present study, two bones, a mandible, an example of the membranous bone, and a long bone, an example of the endochondral bone (Weinman \& Sicher, 1955), were selected to study bone metabolism.

\section{MATERIALS AND METHODS}

A total of thirty-nine time-pregnant Sprague-Dawley rats were used in the experiment. On the 9th day of gestation (the sperm-positive day counted as day 1), dams were randomly divided into four groups. Group 1 control dams $(n 8)$ were injected with citrate buffer only and fed on the $200 \mathrm{~g}$ protein $/ \mathrm{kg}$ diet. Group 2 dams $(n 12)$ were injected through the tail vein with streptozotocin $(40 \mathrm{mg} / \mathrm{kg})$ dissolved in citrate buffer. Group 2 dams were pairfed with group 1 and given the $200 \mathrm{~g}$ protein $/ \mathrm{kg}$ diet. Group 3 control dams $(n 8)$ were given buffer only and fed on the $600 \mathrm{~g}$ protein $/ \mathrm{kg}$ diet. Group 4 dams $(n 11)$ were injected with streptozotocin like group 2 and pair-fed on the $600 \mathrm{~g}$ protein $/ \mathrm{kg}$ diet.

The source of the protein was casein. Diets were isoenergetic and where high protein was given the amount of carbohydrate was appropriately reduced (Table 1). Blood glucose was estimated $48 \mathrm{~h}$ post-injection by Dextrostix (Ames Co., Miles Lab, Elkhart, IN). Only dams with glucose values greater than $2500 \mathrm{mg} / \mathrm{l}$ were accepted as diabetic at this stage. In like manner, the blood of the control dams were also treated using Dextrostix.

On day 22 of gestation, dams from each group $(n 3)$ were injected with ${ }^{45} \mathrm{Ca}$ at a dose of $250 \mu \mathrm{Ci} / \mathrm{kg}$ body-weight. At $1.5 \mathrm{~h}$ post-injection, dams were placed under diethyl ether anaesthesia and blood was collected by cardiac puncture. They were then killed by cervical dislocation. Fetuses were rapidly removed by caesarean section and weighed.

By this time, apparently some dams were recovering from severe diabetic states. Thus, when dams showed blood glucose levels less than $2500 \mathrm{mg} / \mathrm{l}$ by Dextrostix at the time of killing, we measured actual blood glucose levels by the glucose oxidase (EC 1.1.3.4) method (Sigma Chemical Corp., 1982) to make sure that these dams were still diabetic.

The left and right mandibles of each fetus were split in the middle with a sharp knife and removed. The tooth germ of molars and incisors and soft tissue were carefully removed from the mandibular body and discarded. In the growth centres of the long bones, the distal part of the femur and the proximal part of the tibia were removed and cleaned of soft tissue. The distal part of the femur and the proximal part of the tibia included cartilaginous epiphysis and a portion of the developing trabeculae of metaphysis. Both mandibles and long bones were checked under a dissecting microscope to ensure removal of all soft tissue. Using both mandibles and long bones allowed the study of the effect of diabetes on membranous and endochondral bone formation. A cleaned mandible or long bone from each fetus, $0.2 \mathrm{ml}$ perchloric acid $(600 \mathrm{ml} / 1)$ and $0.4 \mathrm{ml}$ hydrogen peroxide $(300 \mathrm{ml} / 1)$ were mixed in a vial and placed in a $75^{\circ}$ oven for $1 \mathrm{~h}$ and oxidized (Nakamoto \& Miller, 1979). Portions of the oxidized samples were subjected to atomic absorption spectrophotometry (Model 280; Fisher Scientific Co., Fair Lawn, NJ) to measure total Ca content of bones. Scintillation fluid $(10 \mathrm{ml})$ and $2 \mathrm{ml}$ tri-n-butyl phosphate were added to the remaining oxidized samples. ${ }^{45} \mathrm{Ca}$ was measured using a liquid-scintillation counter (Model LS-3145T; Beckman Instruments, Irvine, CA).

At $6 \mathrm{~h}$ before death, other dams from each group $(n 5)$ were injected with $\left[\mathrm{U}-{ }^{14} \mathrm{C}\right]$ proline 
Table 1. Composition of diets $(/ \mathrm{kg})$

\begin{tabular}{|c|c|c|}
\hline Protein level $(\mathrm{g} / \mathrm{kg}) \quad \ldots$ & 200 & 600 \\
\hline Casein $(\mathrm{g})$ & 200 & 600 \\
\hline Dextrose $(\mathrm{g})$ & 192 & 52 \\
\hline Sucrose $(\mathrm{g})$ & 178 & 58 \\
\hline Dextrin $(g)$ & 192 & 52 \\
\hline Maize oil (Mazola $\left.{ }^{\star m l}\right)$ & 150 & 150 \\
\hline Mineral mix* $(\mathrm{g})$ & 40 & 40 \\
\hline Choline chloride $(500 \mathrm{~g} / \mathrm{l})(\mathrm{ml})$ & 4 & 4 \\
\hline Cellulose $(\mathrm{g})$ & 35 & 35 \\
\hline Vitamin mix $†(g)$ & 10 & 10 \\
\hline
\end{tabular}

* Roger-Harper mineral mix (Teklad Test Diets, Madison, WI).

$\dagger$ AIN vitamin mixture 76 (ICN Pharmaceuticals, Inc., Cleveland, OH).

at a dose of $65 \mu \mathrm{Ci} / \mathrm{kg}$ body-weight to study collagen synthesis of bones. Mandibles or long bones were prepared as described previously and placed in $10 \mathrm{ml}$ ampoules containing $1.5 \mathrm{ml} 6 \mathrm{M}$-hydrochloric acid. Each ampoule was flushed with nitrogen for $30 \mathrm{~s}$, sealed and placed in an oven at $125^{\circ}$ for $24 \mathrm{~h}$. After cooling, the hydrosylates were filtered through a fritted disc funnel. A $1 \mathrm{ml}$ portion was taken and diluted with $3 \mathrm{ml}$ sodium acetate-citrate buffer at $\mathrm{pH}$ 6. The acid was neutralized by the addition of $6 \mathrm{ml}$ sodium carbonate $(50 \mathrm{~g} / 1)$. Total proline and the radioactivity of $\left[{ }^{14} \mathrm{C}\right]$ proline was measured as described by Nakamoto \& Miller (1979).

Statistical analysis was performed using analysis of variance and multiple comparison (Student-Newman-Keuls) with a 5\% level of significance. Analyses were performed on an Apple II microcomputer (Apple Inc., Cupertino, CA).

\section{RESULTS}

Mean food intakes per day over the experimental period for non-diabetic rats fed on 200 and $600 \mathrm{~g}$ protein $/ \mathrm{kg}$ diets were 25 (SE 1) and 27 (SE 1) g respectively. Mean food intakes per day excluding the first $24 \mathrm{~h}$ for diabetic groups fed on 200 and $600 \mathrm{~g}$ protein $/ \mathrm{kg}$ were 24 (SE 1) and 26 (SE 1) g respectively. Glucose levels of the diabetic dams which showed less than $2500 \mathrm{mg} / \mathrm{l}$ by Dextrostix at the time of killing were 2340 (SE 160) and 1890 (SE 130) $\mathrm{mg} / \mathrm{l}$ for the 200 and $600 \mathrm{~g}$ protein $/ \mathrm{kg}$ diet groups respectively. There was no significant difference between the groups. A total of four dams from group 2 and three dams from group 4 in which glucose levels were between 1200 and $1500 \mathrm{mg} / 1$ were eliminated from the study as marginally diabetic. The body-weights, mandibular and long-bone weights of the fetuses from the diabetic dams in the $200 \mathrm{~g}$ protein $/ \mathrm{kg}$ group were all significantly smaller than those from comparably-nourished, non-diabetic controls. On the other hand, there was no difference between the diabetic and non-diabetic $600 \mathrm{~g}$ protein $/ \mathrm{kg}$ groups in fetal body-weights, and mandibular and long-bone weights. The long-bone weights of the fetuses from the non-diabetic $600 \mathrm{~g}$ protein $/ \mathrm{kg}$ group were smaller than those of the nondiabetic $200 \mathrm{~g}$ protein $/ \mathrm{kg}$ group (Table 2).

The rate of collagen synthesis in the mandibles and long-bones showed no difference between the diabetic and non-diabetic groups fed on the $200 \mathrm{~g}$ protein $/ \mathrm{kg}$ diet. However, the rate of collagen synthesis of the mandibles and long bones in the diabetic $600 \mathrm{~g}$ protein/ $\mathrm{kg}$ group was greater than that of the non-diabetic $600 \mathrm{~g}$ protein $/ \mathrm{kg}$ group (Table 2 ). 


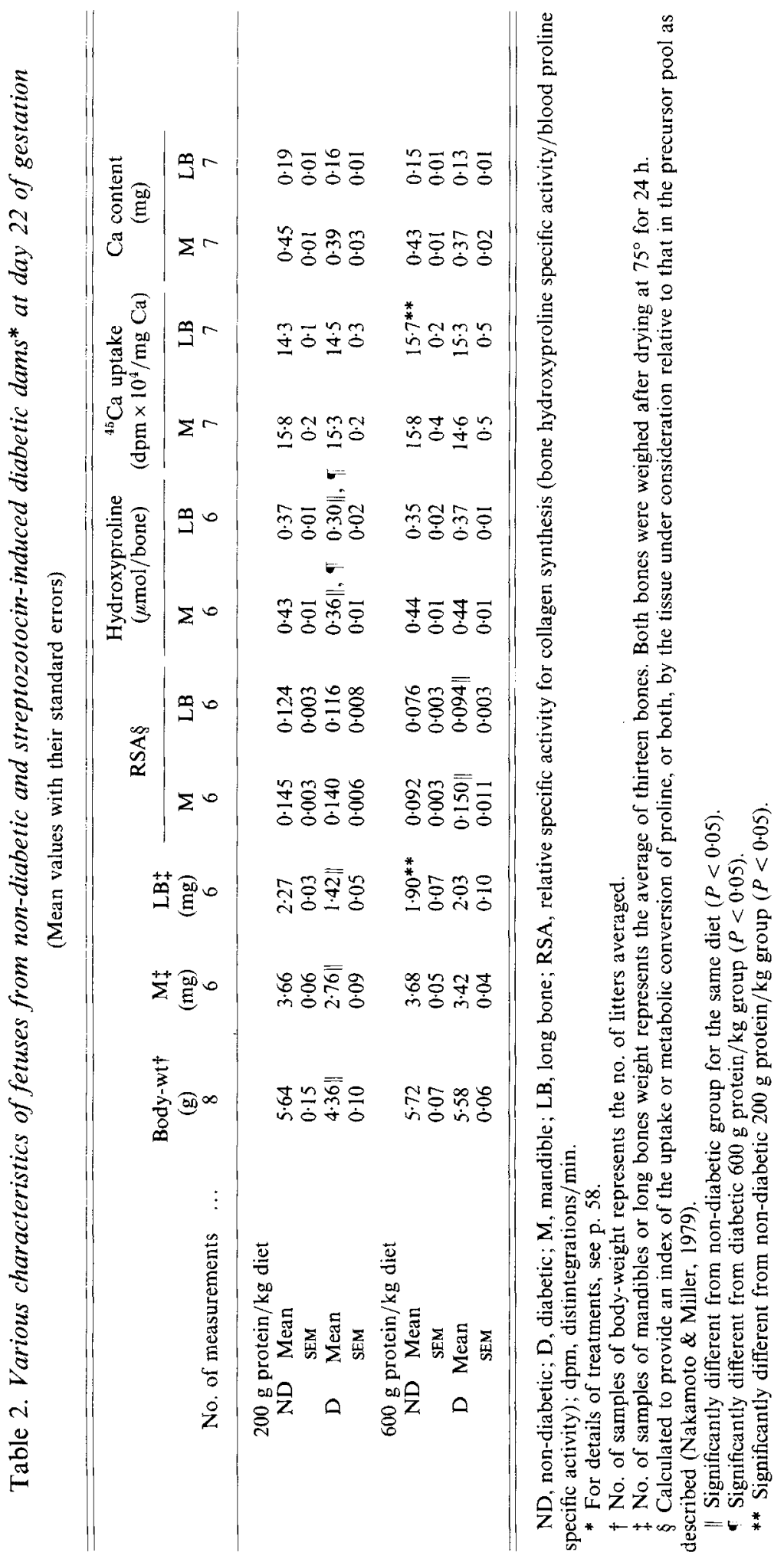


The total hydroxyproline content of the mandibles and long bones in the diabetic 200 $\mathrm{g}$ protein $/ \mathrm{kg}$ group was less than either those of the non-diabetic $200 \mathrm{~g}$ protein $/ \mathrm{kg}$ group or the diabetic $600 \mathrm{~g}$ protein $/ \mathrm{kg}$ group. On the other hand, there was no difference in the total hydroxyproline content of the diabetic and non-diabetic $600 \mathrm{~g}$ protein $/ \mathrm{kg}$ groups for either mandibles or long bones (Table 2).

$\mathrm{Ca}$ uptake of the mandibles and long bones showed no significant difference between the diabetic and non-diabetic groups fed on both diets. Ca uptake of the long bones in the nondiabetic $600 \mathrm{~g}$ protein $/ \mathrm{kg}$ group was greater than that of the non-diabetic $200 \mathrm{~g}$ protein/ $\mathrm{kg}$ group (Table 2). The total Ca contents of the mandibles and long bones in the diabetic group showed no difference from the non-diabetic group for both diets (Table 2).

\section{DISCUSSION}

Various dietary regimens have been advocated in the treatment of patients with diabetes (Perkins et al. 1977; Uribe et al. 1985). In animal studies, a high-protein intake with limited carbohydrate intake in the established diabetic has been shown to be beneficial (Siegel et al. 1980; Eizirik \& Migliorini, 1984).

In both diabetic groups, food intake was practically nil $24 \mathrm{~h}$ after the injection of streptozotocin. However, the difference in food intake between the diabetic and nondiabetic groups was gradually reduced over the next $24 \mathrm{~h}$. It is quite likely that because of the loss of carbohydrate in the urine, availability of energy to the diabetic groups was somewhat less than that to the non-diabetic groups. To compensate, most diabetic animals would have consumed additional food if allowed. Since we fed the same amount of food to the diabetic as to the non-diabetic animals using the pair-feeding method, one can argue that decreased total energy intake in the present study by the diabetic group could have caused certain effects on the developing fetus.

It has been reported that the diabetic rat develops abnormal food intake behaviour compared with non-diabetic rats (Peng et al. 1975), and prefers a high-protein diet (Bellush \& Rowland, 1986). Thus, it is likely that the diabetic 200 and $600 \mathrm{~g}$ protein $/ \mathrm{kg}$ groups might have consumed a different amount of food by ad lib. feeding, resulting in an intake of a different quantity of protein as well as energy. Since diabetic rats fared as well as or better than non-diabetic rats with intake of either energy or protein restricted (Krishnamachar \& Canolty, 1985), and the purpose of the present study was to determine the role of an increased protein content in the maternal diet on the fetus, we have concluded that the effects of dietary protein on the fetal bone metabolism would be maximized by pair-feeding.

In contrast to the human, the offspring born to rats with streptozotocin-induced diabetes are not macrosomic (Eriksson, 1984; Eriksson \& Jansson, 1984). The fetuses born from the diabetic dams fed on the $200 \mathrm{~g}$ protein $/ \mathrm{kg}$ diet showed a significant decrease in bodyweight, as well as in the weights of both bones and their total hydroxyproline content when compared with the non-diabetic group. On the other hand, those characteristics mentioned previously in the diabetic $600 \mathrm{~g}$ protein $/ \mathrm{kg}$ group showed no difference from the nondiabetic animals. This indicates that feeding a $600 \mathrm{~g}$ protein $/ \mathrm{kg}$ diet to the diabetic dams may result in certain beneficial effects on the growth and development of the bones and body-weight.

The total hydroxyproline content reflects the collagen content (Bollet, 1970). Although the rate of collagen synthesis showed no statistical differences between the diabetic and non-diabetic $200 \mathrm{~g}$ protein $/ \mathrm{kg}$ groups for both bones, values of collagen synthesis in the diabetic $200 \mathrm{~g}$ protein $/ \mathrm{kg}$ group were lower than those of the non-diabetic group. It is conceivable that if the difference in the rate of collagen synthesis between the diabetic and 
non-diabetic group is small, this difference might not be detected when biological variation is taken into account. A small difference in collagen synthesis, however, could have made a difference in the collagen content as seen in the present study.

Collagen synthesis in the diabetic $600 \mathrm{~g}$ protein $/ \mathrm{kg}$ groups was greater than that of the non-diabetic groups for both bones. Catabolic processes are enhanced in rats with streptozotocin-induced diabetes (Schneir et al. 1982). Increased catabolism might have been offset by similarly-increased synthesis in the $600 \mathrm{~g}$ protein $/ \mathrm{kg}$ diet groups in the present situation, resulting in approximately the same collagen contents in both bones. It seems that the high-protein, low-carbohydrate diet affected bone matrix formation, possibly altering synthesis and catabolism in these bones.

Calcified ossification centres in various parts of the bones are reported to be decreased by diabetes during pregnancy (Eriksson et al. 1983). We observed no significant difference in the $\mathrm{Ca}$ content and ${ }^{45} \mathrm{Ca}$ uptake of both fetal bones between diabetic and non-diabetic groups fed on the 200 and $600 \mathrm{~g}$ protein $/ \mathrm{kg}$ diets. However, values in the diabetic group tended to be smaller than those of the non-diabetic group.

The present study demonstrated that a high-protein, low-carbohydrate diet may offer certain advantages for the growing fetus born from diabetic dams. An increase in dietary protein appeared to compensate for the altered metabolism in bone development.

The authors wish to express their gratitude to Ms Gay Young and Mr Jimmy Morris whose technical assistance was a great help during the course of this project. This work was supported in part by a grant from the American Diabetic Association, Louisiana Affiliate, Inc. and Research and Grants Committee of Louisiana State University Medical Center.

\section{REFERENCES}

Bellush, L. A. \& Rowland, N. E. (1986). Brain Research Bulletin 17, 653 661.

Bollet, A. J. (1970). Mt Sinai Journal of Medicine 38, 445-449.

Dixit, P. K. \& Stern, A. (1979). Calcified Tissue International 27, 227-232.

Eizirik, D. L. \& Migliorini, R. H. (1984). Diabetes 33, 383-388.

Eriksson, U. J. (1984) Journal of Nutrition 114, 477-484.

Eriksson, U. J., Dalstrom, E. \& Hellerstrom, C. (1983). Diabetes 32, 1141-1145.

Eriksson, U. J. \& Jansson, L. (1984). Pediatric Research 18, $735-738$.

Hahn, T. J., Downing, S. J. \& Phang, J. M. (1971). American Journal of Physiology 220, 1717-1724.

Kelvin, M. \& Frost, M. (1964). Henry Ford Hospital Medical Bulletin 12, 527-536.

Krishmnamachar, S. \& Canolty, N. L. (1985). Nutrition Research 5, 1375-1382.

Lewis, M., Boisseu, V. Avioli, L. (1976). New England Journal of Medicine 294, 241-245.

Nakamoto, T. \& Miller, S. A. (1979). Journal of Nutrition 109, 1469-1476.

Peng, Y., Meliza, L. L., Vavich, M. G. \& Kemmerer, A. R. (1975). Journal of Nutrition 105, 1395-1404.

Perkins, J. R., West, T. E. T., Sonksen, P. H., Lowry, C. \& Iles, C. (1977). Diabetologia 13, 607-614.

Schneider, L. E. \& Schedl, H. P. (1972). American Journal of Physiology 223, 1319-1323.

Schneir, M., Ramamurthy, N. \& Golub, L. (1982). Diabetes 31, 426-431.

Siegel, E. G., Trapp, V. E. \& Schmidt, F. H. (1976). Diabetologia 12, 419-425.

Siegel, E. G., Trapp, V. E., Wollheim, C. B., Reynold, A. E. \& Schmidt, F. H. (1980). Metabolism 5, 42 l 426.

Sigma Chemical Corp. (1982). Sigma Technical Bulletin. no. 510. St Louis, Mo.: Sigma Chemical Corp.

Silberberg, R., Hirshberg, G. E. \& Lesker, P. (1977). Diabetes 26, 732-735.

Uribe, M., Dibildox, M., Malpica, S., Guillermo, F., Villallobos, A., Nieto, L., Vargas, F. \& Ramos, G. G. (1985). Gastroenterology 88, 901-907.

Weinman, J. P. \& Sicher, H. (1955). Bone and Bones: Fundamentals of Bone Biology, pp. 57-58. St Louis, Mo.: C. V. Mosby Co.

Weiss, R. E. \& Reddi, A. H. (1980). American Journal of Physiology 238, E200-207.

Wettenholl, R. H., Schwartz, P. L. \& Bornstein, J. (1969). Diabetes 18, 280-282. 